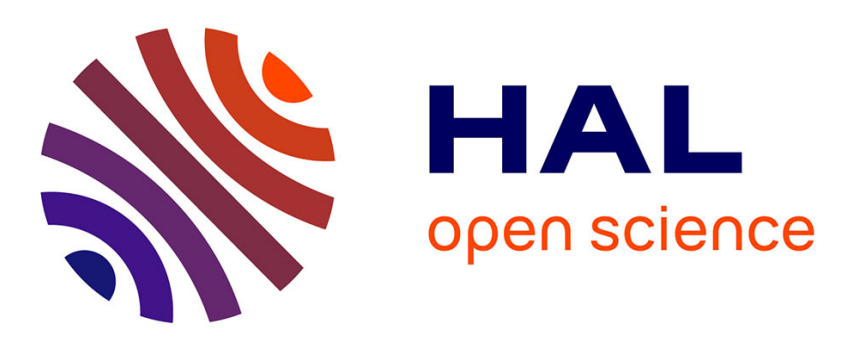

\title{
A Critical Review of Empirical Research Examining SMEs Adoption from Selected Journals
}

S. S. Abed

\section{To cite this version:}

S. S. Abed. A Critical Review of Empirical Research Examining SMEs Adoption from Selected Journals. 17th Conference on e-Business, e-Services and e-Society (I3E), Oct 2018, Kuwait City, Kuwait. pp.577-587, 10.1007/978-3-030-02131-3_50 . hal-02274176

\section{HAL Id: hal-02274176 \\ https://hal.inria.fr/hal-02274176}

Submitted on 29 Aug 2019

HAL is a multi-disciplinary open access archive for the deposit and dissemination of scientific research documents, whether they are published or not. The documents may come from teaching and research institutions in France or abroad, or from public or private research centers.
L'archive ouverte pluridisciplinaire HAL, est destinée au dépôt et à la diffusion de documents scientifiques de niveau recherche, publiés ou non, émanant des établissements d'enseignement et de recherche français ou étrangers, des laboratoires publics ou privés. 


\title{
A critical review of empirical research examining SMEs adoption from selected journals
}

\author{
Salma S. Abed \\ Department of Management Information Systems \\ College of Business (COB) \\ King Abdulaziz University \\ Rabigh, Saudi Arabia \\ sabid@kau.edu.sa
}

\begin{abstract}
The purpose of this paper is to review the literature on empirical research examined Small and Medium size Enterprises (SMEs) from selected journals. This has been achieved by reviewing the most examined constructs to identify the key significant factors in the literature. The selected research papers for reviewing are accessed from only high-ranking journals. The review addressed technology adoption in the context of SMEs. The paper attempts to review the studies based on technology-organisation-environment (TOE) framework to identify the relevant set of variables for technology adoption in SMEs. The most significant factors found to be relative advantage and compatibility from the technological context, top management support and size from the organizational context, and external pressure from the Environmental context. This review intended to guide future researchers to improve the predictive power of their examined models.
\end{abstract}

Keywords: Technology adoption, SMEs, TOE, Empirical Research.

\section{Introduction}

Small and Medium Enterprises (SMEs) are considered one of most significant sectors to promote nations financial and economic growth [3]. SMEs are defined based on their employment and economy figures as well as fixed assets and sales volumes. They typically employ less than 500 workers. They are known for their major advantages including employment creation at low capital cost, flexibility, and innovation [1, 59, 67]. Economies of most OCED nations comprise nearly $96 \%$ to $99 \%$ of small and medium enterprises that account for $80 \%$ economic growth for those nations. Their existence is evident in all developed and developing countries to the extent that GDPs for North American and European countries today is contributed significantly by SMEs with $99 \%$ of all businesses. Apart from that, around $70 \%$ job creation is credited to this sector [65]. SMEs are known for their significant role in driving the economic growth. Governments of emerging nations and developed countries support SMEs sector through encouraging public policies [3]. Large corporations, that normally play their central role in country's formal economy, could not effectively operate in absence of SMEs [2]. In fact, they 
appear more leading where there's a need to rely less on traditional resources and effectively support technology and human intellectual capital as they depends on innovation, change adoption, creation of information and knowledge through strategic disposition of knowledge capital [3, 5, 65].

The existence and growth of SMEs sustain through inter-organizational integration and access to knowledge for which SMEs significantly need resources including Information technology, networking, internet and social media, configurable platforms, and prompt data processing models [1]. Such resources, especially information and communications technology enable SMEs to operate cost-effectively, both at national and international levels [5]. They need to earn and maintain competitive advantage through improved service quality and product expansion, customer evaluations, improved effectiveness and efficiency, cost reduction, and sales forecasting.

Research studies show that SMEs profit heavily by ICT in order to achieve sustainable growth in developed economies $[51,79]$. The beginning of last decade observed a huge increase in the use of online platforms by businesses in the US and Europe. It showed similar growth in other parts of the world where online business ventures added billions to aggregate revenues [3]. Certain factors, however, affect SMEs' economic development and weaken their access to global markets, including ICT adoption. This adoption of ICT by SMEs is yet to be explored fully. This study will review the literature based on the TOE framework constructs in order to identify relevant set of variables for technology adoption in SMEs.

\section{Technology adoption}

Technology adoption is defined as the choice to obtain and use a new innovation [25]. The mental acceptance of a technology by an individual or an organization, and the decision, by an individual or organization, to implement and utilize a technology [80]. Various models and theories have effectively explained technology adoption as voluntary individual behavior including; TAM, IDT, TRA, TRB, TOE, and UTAUT proposed by [17], [62], [22], [6], [75] and [77] respectively.

This technology adoption was categorized at three distinct levels: organization, group, and team [25]. However, some studies show that TRA, TRB, and UTAUT are more aimed at forecasting individual adoption as compared to organizational context. In contrast, the TOE frameworks are mostly used at the organizational level to analyse the technology adoption. In recent years, the TOE frameworks have gained significant value among several authors who employ them to gain theoretical perspective on the ICT adoption as well as to test its variables for acceptance of new technologies [87].

Even though IDT and TOE framework constructs are suitable for examining organizational adoption, TOE frameworks are given more weight due to their addition of new construct (i.e. environmental) in explaining the technology adoption. [87] found TOE framework having more significance than the IDT in their theoretical evaluations. As a 
result, this research study will consider organization-based research studies established on TOE due to their high significance over other frameworks.

\section{TOE Framework}

[75] initially developed the TOE framework in order to analyse the organizational-level adoption of a number of information technology products and services. Since then, TOE frameworks have emerged as significant theoretical perspectives by potential researchers studying technology adoption. The addition of various distinct variables including technological, organizational, and environmental in TOE framework has supplemented researchers to test and validate its advantage over other adoption models w.r.t. their ability to technology use, technology adoption, and value created by SMEs sector as a result of technology creation $[25,59]$. Therefore, there are many reasons to employ the TOE framework due to its many benefits including; its user adoption of ICT, its influence over value chain undertakings, its implementation, its diffusion among organizations after the adoption, foreseeing obstacles, its ability to develop better organizational competencies using the technology, and other factors impacting business decisions related to innovation-adoption. All three contexts of TOE framework, as explained by [75] influence the technological innovation adoption of the framework and its implementation. The following sections briefly outline those three contexts of Technological, Organizational, Environmental (TOE) framework;

Technological Context: According to [15], technological context is set of those variables that shadow their influence over individuals, organizations, and industries in their process of adopting innovations. [18] Further divided it into five innovation attributes that influence the possibility of adoption. A deep insight into technological context reveals that the adoption relies on various technologies, both inside and outside the organization. Moreover, it depends on application's apparent relative advantage, complexity in terms of learning curve, observability (imagination), compatibility (organizational as well as technical), and trialability (experimentation).

Organizational Context: organizational context comprises of organization's culture, business scope, top management's support, organizational readiness, prior ICT knowledge, owner innovativeness, information intensity, cost, and size [75].

Environmental Context: Factors facilitating or delaying areas of operation are covered under environmental context. [87, 8, and 65] have captured a number of significant factors including competitive pressure, socio-cultural issues, readiness of business partners, government support and encouragement, and infrastructures for technology support. 


\section{Empirical studies on SMEs innovation adoption from select journals}

Based on the academic journal guide 2015, a literature review was directed to identify the empirical publications conducted on SMEs innovation adoption from high-ranking journals. Thirty-five journals has published empirical studies on SMEs innovation adoption, ranging from $4 *$ to $1 *$ rating, and a total of sixty-eight studies was identified (Table 1). These studies were conducted from 1995 to 2017 , the highest number of studies has took place in 2005 (Figure 1).

Table 1. Empirical studies on SMEs innovation adoption from select journals

\begin{tabular}{|c|c|c|c|c|}
\hline ISSN & Journal name & $\begin{array}{l}\text { AJG } 2015 \\
\text { Rating }\end{array}$ & $\begin{array}{l}\text { ABS 2010 } \\
\text { Rating }\end{array}$ & Articles \\
\hline 0276-7783 & MIS quarterly & 4 & 4 & {$[32]$} \\
\hline $1047-7047$ & Information systems research & 4 & 4 & {$[73] ;[84]$} \\
\hline 0025-1909 & Management science & 4 & 4 & {$[86]$} \\
\hline 0883-9026 & Journal of Business Venturing & 4 & 4 & [34];[63] \\
\hline $0022-2437$ & Journal of marketing research & 4 & 4 & [24] \\
\hline $0047-2506$ & $\begin{array}{l}\text { Journal of International Busi- } \\
\text { ness Studies }\end{array}$ & 4 & 4 & [27] \\
\hline 0143-2095 & $\begin{array}{l}\text { Strategic Management Jour- } \\
\text { nal }\end{array}$ & 4 & 4 & [71] \\
\hline $1042-2587$ & $\begin{array}{l}\text { Entrepreneurship Theory and } \\
\text { Practice }\end{array}$ & 4 & 4 & {$[48]$} \\
\hline $0090-4848$ & Human resource management & 4 & 4 & {$[30]$} \\
\hline $0378-7206$ & Information \& management & 3 & 3 & $\begin{array}{l}{[12] ;[16] ;[28] ;} \\
{[31] ;[36][46] ;} \\
{[49] ;[54] ;[61]}\end{array}$ \\
\hline $0925-5273$ & $\begin{array}{l}\text { International Journal of Pro- } \\
\text { duction Economics }\end{array}$ & 3 & 3 & [14] \\
\hline 0921-898X & Small Business Economics & 3 & 3 & [19] \\
\hline $0963-8687$ & $\begin{array}{l}\text { Journal of Strategic Infor- } \\
\text { mation System }\end{array}$ & 3 & 3 & {$[35]$} \\
\hline $0309-0566$ & $\begin{array}{l}\text { European Journal of Market- } \\
\text { ing }\end{array}$ & 3 & 3 & [38];[64] \\
\hline 0960-085X & $\begin{array}{l}\text { European Journal of Infor- } \\
\text { mation Systems }\end{array}$ & 3 & 3 & [53]; [85];[87] \\
\hline $0305-0483$ & $\begin{array}{l}\text { Omega: The International } \\
\text { Journal of Management Sci- } \\
\text { ence }\end{array}$ & 3 & 3 & {$[56] ;[74]$} \\
\hline $1086-4415$ & $\begin{array}{l}\text { International Journal of Elec- } \\
\text { tronic Commerce }\end{array}$ & 3 & 3 & [70] \\
\hline $0742-1222$ & $\begin{array}{l}\text { Journal of management infor- } \\
\text { mation systems }\end{array}$ & 4 & 3 & [72] \\
\hline $0266-2426$ & $\begin{array}{l}\text { International Small Business } \\
\text { Journal }\end{array}$ & 3 & 3 & {$[45]$} \\
\hline $0166-4972$ & Technovation & 3 & 3 & {$[44] ;[60] ;[83]$} \\
\hline $0047-2778$ & $\begin{array}{l}\text { Journal of Small Business } \\
\text { Management }\end{array}$ & 3 & 3 & {$[10] ;[78] ;[81]$} \\
\hline
\end{tabular}




\begin{tabular}{|c|c|c|c|c|}
\hline $1462-6004$ & $\begin{array}{l}\text { Journal of Small Business and } \\
\text { Enterprise Development }\end{array}$ & 2 & 2 & $\begin{array}{l}{[21] ;} \\
{[25] ;[39] ;[40] ;} \\
{[58]}\end{array}$ \\
\hline $0003-6846$ & Applied Economics & 2 & 2 & [33] \\
\hline $0955-534 X$ & European Business Review & 2 & 2 & [37] \\
\hline $0887-4417$ & $\begin{array}{l}\text { Journal of Computer Infor- } \\
\text { mation Systems }\end{array}$ & 2 & 2 & [47] \\
\hline $1529-3181$ & $\begin{array}{l}\text { Communications of the Asso- } \\
\text { ciation for Information Sys- } \\
\text { tems }\end{array}$ & 2 & 2 & [52] \\
\hline $1062-7375$ & $\begin{array}{l}\text { Journal of Global Infor- } \\
\text { mation Management }\end{array}$ & 2 & 2 & [76] \\
\hline $0268-4012$ & $\begin{array}{l}\text { International Journal of Infor- } \\
\text { mation Management }\end{array}$ & 2 & 2 & [43] \\
\hline 1086-1718 & Strategic Change & 2 & 2 & [29] \\
\hline $1467-0895$ & $\begin{array}{l}\text { International Journal of Ac- } \\
\text { counting Information Systems }\end{array}$ & 2 & 1 & [11] \\
\hline $1019-6781$ & Electronic Markets & 2 & 1 & $\begin{array}{l}7] ;[8] ; \\
{[41] ;[54] ;[82]}\end{array}$ \\
\hline 1741-0398 & $\begin{array}{l}\text { Journal of Enterprise Infor- } \\
\text { mation Management }\end{array}$ & 2 & 1 & $\begin{array}{l}{[9] ;[13] ;[23] ;} \\
{[59] ;[65][69]}\end{array}$ \\
\hline $0263-5577$ & $\begin{array}{l}\text { Industrial Management and } \\
\text { Data Systems }\end{array}$ & 2 & 1 & {$[4] ;[26] ;[57] ;[68]$} \\
\hline $1741-0401$ & $\begin{array}{l}\text { International Journal of } \\
\text { Productivity and Performance } \\
\text { Management }\end{array}$ & 1 & 1 & [50] \\
\hline Total & 35 & & & 68 \\
\hline
\end{tabular}

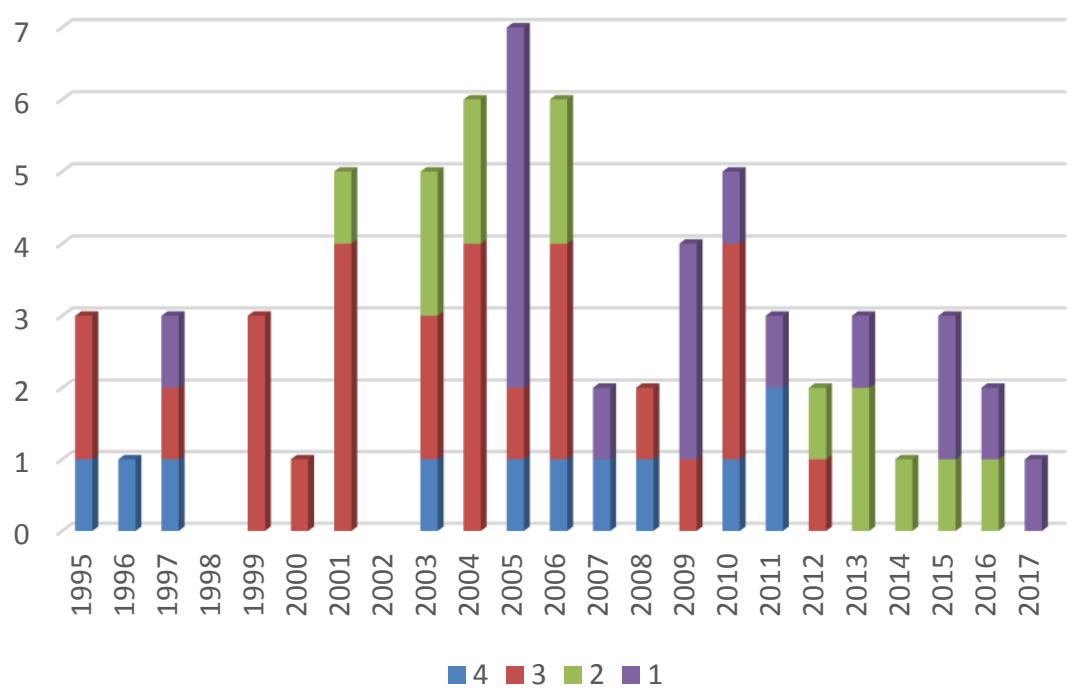

Figure 1. Empirical studies conducted according to journal rating and year 
Based on TOE framework, a construct analysis has conducted to identify the most significant factors affecting SMEs adoption from the studies that has been identified in Table 1 . From the technological factors, six constructs has been identified including relative advantage, compatibility, complexity, trialability, observability, and security. From the organizational factors, seven constructs has been identified including top management support, organizational readiness, prior ICT/IS knowledge, owner/ entrepreneurial innovativeness, information intensity, cost, and size. From the environmental factors, five constructs has been identified including external/competitive pressure, consumer pressure, industry sector, market scope, and external ICT support (Table 2).

Table 2. Construct analysis the most significant factors affecting SMEs adoption

\begin{tabular}{|c|c|c|}
\hline IV & Significant & Insignificant \\
\hline \multicolumn{3}{|c|}{ Technological factors } \\
\hline $\mathrm{R}$ & DV: BI [43];[61] & DV:USE [7];[8] \\
\hline A & $\begin{array}{l}\text { DV:USE[9];[12];[25];[26];[28];[32];[33];[35];[36];[446];[4 } \\
\text { 7];[49];[52];[53];[54];[55];[56];[65]; [68];[70];[[76]; [58] }\end{array}$ & \\
\hline $\begin{array}{l}\mathrm{C} \\
\mathrm{B}\end{array}$ & $\begin{array}{l}\text { DV:USE[4];[7];[8];[9];[12];[25];[26];[28];[35];[47];[49];[ } \\
\text { 52] [54];[58];[68];;70];[76];[85] }\end{array}$ & \\
\hline $\begin{array}{l}\mathrm{C} \\
\mathrm{X}\end{array}$ & DV:USE [8];[9];[49];[58];[61];[68];[76] & $\begin{array}{l}\text { DV: BI [43] } \\
\text { DV:USE [35];[28] }\end{array}$ \\
\hline TR & DV:USE [9];[35]; [58];[59];[68];[82] & DV:USE [8] \\
\hline $\begin{array}{l}\mathrm{O} \\
\mathrm{B}\end{array}$ & DV:USE [58];[68] & DV:USE [8];[35];[59] \\
\hline SC & DV:USE [40];[19];[21];[85];[68] & \\
\hline \multicolumn{3}{|c|}{ Organizational factors } \\
\hline $\mathrm{T}$ & DV: BI [43] & \\
\hline M & DV:USE[9];[12];[14];[47];[49];[54];[55];[56];[58];[59];[6 & \\
\hline $\mathrm{S}$ & 5];[70];[84] & \\
\hline $\mathrm{O}$ & DV: BI [14] & DV: BI [47] \\
\hline $\mathrm{R}$ & $\begin{array}{l}\text { DV:USE[28];[32];[36];[46];[47];[49];[52];[58];[59];[82];[ } \\
86]\end{array}$ & \\
\hline PK & DV:USE [7];[19];[26];[33];[40];[72];[73];[74];[76];[82] & DV:USE [26];[58];[59] \\
\hline OI & $\begin{array}{l}\text { DV:USE[7];[21];[25];[26];[33];[39];[72];[73];[74];[76];[8 } \\
\text { 2] }\end{array}$ & \\
\hline II & $\begin{array}{l}\text { DV: BI [26];[72];[74] } \\
\text { DV:USE [26];[37];[41];[54] }\end{array}$ & DV: BI [7];[70] \\
\hline $\begin{array}{l}\mathrm{C} \\
\mathrm{O}\end{array}$ & $\begin{array}{l}\text { DV: BI [43] } \\
\text { DV:USE [4];[8];[21];[25];[40];[82];[84];[85] }\end{array}$ & $\begin{array}{l}\text { DV:USE[7];[8];[35];[26 } \\
\text { ]; [33] }\end{array}$ \\
\hline SI & $\begin{array}{l}\text { DV:USE[7];[9];[13];[19];[31];[49];[56];[58];[59];[69];[72 } \\
\text { ];[73];[74];[76];[84];[87] }\end{array}$ & DV:USE [26];[33] \\
\hline \multicolumn{3}{|c|}{ Environmental factors } \\
\hline EP & $\begin{array}{l}\text { DV:USE[14];[19];[26];[28];[32];[36];[56];[46];[52];[58];[ } \\
\text { 76];[82];[84];[85];[86];[87] }\end{array}$ & $\begin{array}{l}\text { DV: BI [43] } \\
\text { DV:USE[7];[9];[33];[37 } \\
\text { ];[47];[49];[59]; [70] }\end{array}$ \\
\hline $\mathrm{CP}$ & $\begin{array}{l}\text { DV: BI [43] } \\
\text { DV:USE [21];[41];[53];[82];[87];[65];[39];[26] }\end{array}$ & \\
\hline IS & DV:USE [9];[14];[21];[31];[53];[54];[58];[69] & DV:USE [59] \\
\hline
\end{tabular}




\begin{tabular}{|l|l|l|}
\hline $\begin{array}{l}\text { M } \\
\text { S }\end{array}$ & DV:USE [9];[33];[37];[58];[59];[84];[87] & DV:USE [13];[86] \\
\hline ES & DV:USE [9];[26];[65];[82] & DV:USE [7];[58];[59] \\
\hline
\end{tabular}

IV: Independent variable, DV: Dependent variable, BI: Behavioural Intention, RA: Relative advantage, CB: Compatibility, CX: Complexity, TR: Trialability, OB: observability, SC: Security, TMS: Top management support, OR: Organizational readiness, PK: ICT/IS Prior knowledge , OI: Owner Innovativeness, II: Information Intensity, CO: Cost, SI: Size, EP: External Pressure, CP: Consumer pressure, IS: Industry sector, MS: Market Scope, ES: External ICT Support.

\section{Summary and conclusion}

The current study makes a significant contribution for academics by reviewing the literature of the empirical studies on SMEs innovation adoption from high-ranking journals. A total of thirty-five journals have presented empirical research papers on SMEs innovation adoption with sixty-eight different studies. The identified studies has been conducted from 1995 to 2017. Based on the TOE framework, a review of the constructs has directed to identify the most significant factors affecting SMEs innovation adoption from the selected journals. The study found that the most significant factors found to be relative advantage and compatibility from the technological context, top management support and size from the organizational context, and external pressure from the environmental context. This analysis intended to guide future researchers to improve the predictive power of their examined models. 


\section{References:}

1. Abed, S. S., Dwivedi, Y. K., and Williams, M. D.: SMEs' adoption of e-commerce using social media in a Saudi Arabian context: a systematic literature review. International. Journal of Business Information Systems, 19(2), 159-179 (2015a)

2. Abed, S. S., Dwivedi, Y. K., and Williams, M. D.: Social media as a bridge to e-commerce adoption in SMEs: a systematic literature review. The Marketing Review, 15(1), 39-57 (2015b)

3. Abed, S. S., Dwivedi, Y. K., and Williams, M. D.: Social Commerce as a Business Tool in Saudi Arabia's SMEs. International Journal of Indian Culture and Business Management, 13(1), 1-19 (2016)

4. Ainin, S., Parveen, F., Moghavvemi, S., Jaafar, N. I., and Mohd Shuib, N. L.: Factors influencing the use of social media by SMEs and its performance outcomes. Industrial Management \& Data Systems, 115(3), 570-588 (2015)

5. Ajmal, F., Yasin, N. M., and Norman, A. A.: Critical success factors influencing e-commerce adoption in SMEs: A review and model. International Journal of Advanced and Applied Sciences, 4(7), 159-172 (2017)

6. Ajzen, I.: The theory of planned behaviour. Organizational Behaviour and Human Decision Processes, 50(2), 179-211(1991)

7. Al-Qirim, N.: An Empirical Investigation of an e-commerce Adoption-Capability Model in Small Businesses in New Zealand. Electronic Markets, 15(4), 418-437 (2005)

8. Al-Qirim, N.: A Research Trilogy into E-Commerce Adoption in Small Businesses in New Zealand. Electronic Markets, 17(4), 263-285 (2007)

9. Alshamaila, Y., Papagiannidis, S., and Li, F.: Cloud computing adoption by SMEs in the north east of England: A multi-perspective framework. Journal of Enterprise Information Management, 26(3), 250-275 (2013)

10. Aragón-Sánchez, A., and Sánchez-Marín, G.: Strategic orientation, management characteristics, and performance: A study of Spanish SMEs. Journal of Small Business Management, 43(3), 287-308 (2005)

11. Azmi, A., Sapiei, N. S., Mustapha, M. Z., and Abdullah, M.: SMEs' tax compliance costs and IT adoption: the case of a value-added tax. International Journal of Accounting Information Systems, 23, 1-13 (2016)

12. Beatty, R. C., Shim, J. P., and Jones, M. C.: Factors influencing corporate web site adoption: a time-based assessment. Information $\&$ management, 38(6), 337-354 (2001)

13. Buonanno, G., Faverio, P., Pigni, F., Ravarini, A., Sciuto, D., and Tagliavini, M.: Factors affecting ERP system adoption: a comparative analysis between SMEs and large companies. Journal of Enterprise Information Management, 18(4), 384-426 (2005)

14. Chan, F. T., Yee-Loong Chong, A., and Zhou, L.: An empirical investigation of factors affecting e-collaboration diffusion in SMEs. International Journal of Production Economics, 138(2), 329-344 (2012) 
15. Cindy Claycomba, C., Iyerb, K., and Germainc, R.: Predicting the level of $\mathrm{B} 2 \mathrm{~B}$ e-commerce in industrial organizations. Industrial Marketing Management, 34, $221-234$ (2005)

16. Cragg, P. B. and Zinatelli, N.: The evolution of information systems in small firms. Information \& Management, 29(1), 1-8 (1995)

17. Davis, F. D.: Perceived usefulness, perceived ease of use, and user acceptance of information technology. MIS Quarterly, 13(3), 319-340 (1989)

18. Dedrick, J. and West, J.: Why firms adopt open source platforms: A grounded theory of innovation and standards adoption. Proceedings of the Workshop on Standard Making: A Critical Research Frontier for Information Systems (2003)

19. Dholakia, R. R., and Kshetri, N.: Factors impacting the adoption of the internet among SMEs. Small Business Economics, 23(4), 311-322 (2004)

20. Dwivedi, Y. K., Wastell, D., Laumer, S., Henriksen, H. Z., Myers, M. D., Bunker, D., and Srivastava, S. C.: Research on information systems failures and successes: Status update and future directions. Information Systems Frontiers, 17(1), 143-157 (2015)

21. Fillis, I., Johansson, U., and Wagner, B.: A qualitative investigation of smaller firm e-business development. Journal of Small Business and Enterprise Development, 11(3), 349-361 (2004)

22. Fishbein, $M$ and Ajzen, Icek.: Belief, attitude, intention and behaviour: An introduction to theory and research, (1975)

23. Gangwar, H., Date, H., and Ramaswamy, R.: Understanding determinants of cloud computing adoption using an integrated TAM-TOE model. Journal of Enterprise Information Management, 28(1), 107-130 (2015)

24. Gatignon, H., and Xuereb, J. M.: Strategic orientation of the firm and new product performance. Journal of marketing research, 77-90 (1997)

25. Ghobakhloo, M., and Tang, S. H.: The role of owner/manager in adoption of electronic commerce in small businesses: The case of developing countries. Journal of Small Business and Enterprise Development, 20(4), 754-787 (2013)

26. Ghobakhloo, M., Arias-Aranda, D., and Benitez-Amado, J.: Adoption of ecommerce applications in SMEs. Industrial Management \& Data Systems, 111(8), 1238-1269 (2011)

27. Golovko, E. and Valentini, G.: Exploring the complementarity between innovation and export for SMEs' growth. Journal of International Business Studies, 42(3), 362-380 (2011)

28. Grandon, E. E., and Pearson, J. M.: Electronic commerce adoption: an empirical study of small and medium US businesses. Information \& management, 42(1), 197-216 (2014)

29. Hamad, H., Elbeltagi, I., Jones, P., and El-Gohary, H.: Antecedents of B2B ECommerce Adoption and its Effect on Competitive Advantage in Manufacturing SMEs. Strategic Change, 24(5), 405-428 (2015)

30. Hayton, J. C.: Strategic human capital management in SMEs: An empirical study of entrepreneurial performance. Human resource management, 42(4), 375-391 (2003) 
31. Hong, W., and Zhu, K.: Migrating to internet-based e-commerce: factors affecting e-commerce adoption and migration at the firm level. Information \& Management, 43(2), 204-221 (2006)

32. Iacovou, C. L., Benbasat, I., and Dexter, A. S.: Electronic data interchange and small organizations: adoption and impact of technology. MIS quarterly, 465-485 (1995)

33. Jeon, B. N., Han, K. S., \& Lee, M. J.: Determining factors for the adoption of e-business: the case of SMEs in Korea. Applied Economics, 38(16), 19051916 (2006)

34. Keh, H. T., Nguyen, T. T. M., and Ng, H. P.: The effects of entrepreneurial orientation and marketing information on the performance of SMEs. Journal of Business Venturing, 22(4), 592-611 (2007)

35. Kendall, J.D., Tung, L.L., Chua, K.H., Ng, C.H.D. and Tan, S.M.: Receptivity of Singapore's SMEs to electronic commerce adoption, Journal of Strategic Information Systems, 10(3), 223-42 (2001)

36. Kuan, K. K. and Chau, P. Y.: A perception-based model for EDI adoption in small businesses using a technology-organization-environment framework. Information \& Management, 38(8), 507-521 (2001)

37. Kula, V. and Tatoglu, E.: An exploratory study of Internet adoption by SMEs in an emerging market economy. European Business Review, 15(5), 324-333 (2003)

38. Laforet, S.: Effects of size, market and strategic orientation on innovation in non-high-tech manufacturing SMEs. European Journal of Marketing, 43(1/2), 188-212 (2009)

39. Laforet, S. and Tann, J.: Innovative characteristics of small manufacturing firms. Journal of Small Business and Enterprise Development, 13(3), 363-380 (2006)

40. Lawson, R., Alcock, C., Cooper, J., and Burgess, L.: Factors affecting adoption of electronic commerce technologies by SMEs: an Australian study. Journal of small business and enterprise development, 10(3), 265-276 (2003)

41. Levenburg, N. M.: Does Size Matter? Small Firms' Use of E-Business Tools in the Supply Chain. Electronic markets, 15(2), 94-105 (2005)

42. Lin, H. F. and Lin, S. M.: Determinants of e-business diffusion: a test of the technology diffusion perspective. Technovation, 28(3), 135-145 (2008)

43. Maduku, D. K., Mpinganjira, M., and Duh, H.: Understanding mobile marketing adoption intention by South African SMEs: A multi-perspective framework. International Journal of Information Management, 36(5), 711-723 (2016)

44. Massa, S. and Testa, S.: Innovation and SMEs: Misaligned perspectives and goals among entrepreneurs, academics, and policy makers. Technovation, 28(7), 393-407 (2008)

45. McAdam, R., Moffett, S., Hazlett, S. A., and Shevlin, M.: Developing a model of innovation implementation for UK SMEs: A path analysis and explanatory case analysis. International Small Business Journal, 28(3), 195-214 (2010)

46. Mehrtens, J., Cragg, P. B., and Mills, A. M.: A model of Internet adoption by SMEs. Information \& management, 39(3), 165-176(2001) 
47. Mirchandani, A. A. and Motwani, J.: Understanding Small Business Electronic Commerce Adoption: An Empirical Analysis. Journal of Computer Information Systems Spring, 70-3 (2001)

48. Moreno, A. M. and Casillas, J. C.: Entrepreneurial orientation and growth of SMEs: A causal model. Entrepreneurship Theory and Practice, 32(3), 507-528 (2008)

49. Oliveira, T., Thomas, M., and Espadanal, M.: Assessing the determinants of cloud computing adoption: An analysis of the manufacturing and services sectors. Information \& Management, 51(5), 497-510 (2014)

50. O'Regan, N. and Ghobadian, A.: Innovation in SMEs: the impact of strategic orientation and environmental perceptions. International Journal of Productivity and Performance Management, 54(2), 81-97 (2005)

51. Orser, B. J. and Riding, A.: The influence of gender on the adoption of technology among SMEs. International Journal of Entrepreneurship and Small Business, 33(4), 514-531 (2008)

52. Pearson, J. M. and Grandon, E.: E-commerce adoption: perceptions of managers/owners of small and medium sized firms in Chile. The Communications of the Association for Information Systems, 13(1), 46 (2004)

53. Poon, S.: Business environment and internet commerce benefit-a small business perspective. European Journal of Information Systems, 9(2), 72-81 (2000)

54. Poon, S. and Swatman, P.: An exploratory study of small business Internet commerce issues. Information \& Management, 35(1), 9-18 (1999)

55. Poon, S. and Swatman, P. M.: Internet-based small business communication: seven Australian cases. Electronic Markets, 7(2), 15-21 (1997)

56. Premkumar, G. and Roberts, M.: Adoption of new information technologies in rural small businesses. Omega, 27(4), 467-484 (1999)

57. Puklavec, B., Oliveira, T., and Popovič, A.: Understanding the determinants of business intelligence system adoption stages: an empirical study of SMEs. Industrial Management \& Data Systems, (just-accepted), 00-00 (2017)

58. Ramdani, B., Chevers, D., and Williams, D. A.: SMEs' adoption of enterprise applications: A technology-organisation-environment model. Journal of Small Business and Enterprise Development, 20(4), 735-753 (2013)

59. Ramdani, B., Kawalek, P., and Lorenzo, O.: Knowledge management and enterprise systems adoption by SMEs: Predicting SMEs' adoption of enterprise systems. Journal of Enterprise Information Management, 22(1/2), 10-24 (2009)

60. Rhee, J., Park, T., and Lee, D. H.: Drivers of innovativeness and performance for innovative SMEs in South Korea: Mediation of learning orientation. Technovation, 30(1), 65-75 (2010)

61. Riemenschneider, C. K., Harrison, D. A., and Mykytyn Jr, P. P.: Understanding IT adoption decisions in small business: integrating current theories. Information \& Management, 40(4), 269-285 (2003)

62. Rogers, E.: Diffusion of innovations (4th ed.). New York: The Free Press, (1995) 
63. Rosenbusch, N., Brinckmann, J., and Bausch, A.: Is innovation always beneficial? A meta-analysis of the relationship between innovation and performance in SMEs. Journal of Business Venturing, 26(4), 441-457 (2011)

64. Salavou, H., Baltas, G., and Lioukas, S.: Organisational innovation in SMEs: the importance of strategic orientation and competitive structure. European journal of marketing, 38(9/10), 1091-1112 (2004)

65. Scupola, A.: SMEs' e-commerce adoption: Perspectives from Denmark and Australia. Journal of Enterprise Information Management, 22(1/2), 152-166 (2009)

66. Soto-Acosta, P., Colomo-Palacios, R., and Popa, S.: Web knowledge sharing and its effect on innovation: an empirical investigation in SMEs. Knowledge Management Research \& Practice, 12(1), 103-113 (2014)

67. Sunday, E. Z. E.: Examining Information Communication Technology (ICT) Adoption In SMEs: A Dynamic Capabilities Approach. Journal of Enterprise Information Management, (just-accepted), 00-00 (2018).

68. Tan, K. S., Chong, S. C., Lin, B., and Eze, U. C.: Internet-based ICT adoption: evidence from Malaysian SMEs. Industrial Management \& Data Systems, 109(2), 224-244 (2009)

69. Tan, K. S., Chong, S. C., Lin, B., and Eze, U. C.: Internet-based ICT adoption among SMEs: demographic versus benefits, barriers, and adoption intention. Journal of enterprise information management, 23(1), 27-55 (2010)

70. Teo, T. S., Tan, M., and Buk, W. K.: A contingency model of Internet adoption in Singapore. International Journal of Electronic Commerce, 95-118 (1997)

71. Terziovski, M.: Innovation practice and its performance implications in small and medium enterprises (SMEs) in the manufacturing sector: a resource-based view. Strategic Management Journal, 31(8), 892-902 (2010)

72. Thong, J. Y.: An integrated model of information systems adoption in small businesses. Journal of management information systems, 15(4), 187-214 (1999)

73. Thong, J. Y., Yap, C. S., and Raman, K. S.: Top management support, external expertise and information systems implementation in small businesses. Information systems research, 7(2), 248-267 (1996)

74. Thong, J.Y.L. and Yap, C.S.: CEO characteristics, organizational characteristics and information technology adoption in small businesses, Omega - International Journal of Management Science, Vol. 23 No. 4, pp. 429-42 (1995)

75. Tornatzky, L. and Fleischer, M.: The process of technology innovation. Lexington, M.A: Lexington Books, (1990)

76. Van Huy, L., Rowe, F., Truex, D., and Huynh, M. Q.: An empirical study of determinants of e-commerce adoption in SMEs in Vietnam: An economy in transition. Journal of Global Information Management (JGIM), 20(3), 23-54 (2012)

77. Venkatesh, Viswanath, Morris, G., Michael, Davis, B., Gordon, Davis, and Fred: User Acceptance of Information Technology: Toward a Unified View. MIS Quarterly, 27, 425-478 (2003) 
78. Verhees, F. J. and Meulenberg, M. T.: Market orientation, innovativeness, product innovation, and performance in small firms. Journal of small business management, 42(2), 134-154 (2004)

79. Widyastuti, D. and Irwansyah, I.: Benefits And Challenges Of Cloud Computing Technology Adoption In Small And Medium Enterprises (SMEs). Bandung Creative Movement (BCM) Journal, 4(1), 241-246 (2018)

80. Williams, M. D., Rana, N. P., and Dwivedi, Y. K.: The unified theory of acceptance and use of technology (UTAUT): a literature review. Journal of Enterprise Information Management, 28(3), 443-488 (2015)

81. Wolff, J. A. and Pett, T. L.: Small-Firm Performance: Modeling the Role of Product and Process Improvements. Journal of Small Business Management, 44(2), 268-284 (2006)

82. Wymer, S. A. and Regan, E. A.: Factors Influencing e-commerce Adoption and Use by Small and Medium Businesses. Electronic Markets, 15(4), 438$453(2005)$

83. Zeng, S. X., Xie, X. M., and Tam, C. M.: Relationship between cooperation networks and innovation performance of SMEs. Technovation, 30(3), 181194 (2010)

84. Zhu, K. and Kraemer, K. L.: Post-adoption variations in usage and value of ebusiness by organizations: cross-country evidence from the retail industry. Information Systems Research, 16(1), 61-84 (2005)

85. Zhu, K., Dong, S., Xu, S. X., and Kraemer, K. L.: Innovation diffusion in global contexts: determinants of post-adoption digital transformation of European companies. European Journal of Information Systems, 15(6), 601-616 (2006a)

86. Zhu, K., Kraemer, K. L., and Xu, S.: The process of innovation assimilation by firms in different countries: a technology diffusion perspective on e-business. Management science, 52(10), 1557-1576 (2006b)

87. Zhu, K., Kraemer, K., and Xu, S.: Electronic business adoption by European firms: A cross-country assessment of the facilitators and inhibitors. European Journal of Information Systems, 12, 251-268 (2003)

Biographical notes: Salma S. Abed is an assistant professor in the management information systems department at the College of Business in King Abdulaziz University, Rabigh, Saudi Arabia. She obtained her PhD from the Management School at Swansea University, Wales, UK. She received her MSc in Business Information Technology from the College of Computing and Digital Media at DePaul University, Chicago, Illinois, USA. 